Article

\title{
Effect of Acute and Prolonged Inflammation on the Gene Expression of Proinflammatory Cytokines and Their Receptors in the Anterior Pituitary Gland of Ewes
}

\author{
Karolina Wojtulewicz*®D, Agata Krawczyńska®, Dorota Tomaszewska-Zaremba®, \\ Maciej Wójcik ${ }^{(1)}$ and Andrzej P. Herman ${ }^{(\mathbb{D}}$ \\ The Kielanowski Institute of Animal Physiology and Nutrition, Polish Academy of Sciences, Instytucka 3, \\ 03-105 Jabłonna, Poland; a.krawczynska@ifzz.pl (A.K.); d.tomaszewska@ifzz.pl (D.T.-Z.); \\ m.wojcik@ifzz.pl (M.W.); a.herman@ifzz.pl (A.P.H.) \\ * Correspondence: k.wojtulewicz@ifzz.pl
}

Received: 29 July 2020; Accepted: 20 September 2020; Published: 21 September 2020

\begin{abstract}
An acute and prolonged inflammation inhibits the reproduction process by the disruption of the neurohormonal activity of the hypothalamic-pituitary-gonadal axis. It is thought that these changes may be caused by proinflammatory cytokines, i.e., interleukin (IL) $-1 \beta$, IL- 6 and tumor necrosis factor (TNF) $\alpha$. The aim of this study was to determine the effect of an acute and prolonged inflammation on the expression of genes encoding cytokine and their receptors, gonadotropin releasing hormone receptor $(G n R H R)$, beta subunits of luteinizing hormone $(L H \beta)$ and follicle-stimulating $(F S H \beta)$ in the anterior pituitary (AP). Moreover, the circulating concentration of LH and FSH was also assayed. Two experiments were carried out on adult ewes which were divided into two control groups and treated with lipopolysaccharide (LPS; $400 \mathrm{ng} / \mathrm{kg}$ ). Acute inflammation was caused by a single injection of LPS into the external jugular vein, while the chronic inflammation was induced by seven times LPS injection (one a day). In both experiments, animals were euthanized $3 \mathrm{~h}$ after the last LPS / NaCl injection and the blood samples collected $15 \mathrm{~min}$ before euthanasia. An acute inflammation stimulates the expression of the $I L-1 \beta, I L-6$ and $T N F \alpha$ genes and their receptors in the AP of sheep. Prolonged inflammation increased TNF $\alpha$ gene expression and both types of TNF $\alpha$ and IL-6 receptors. Both an acute and prolonged inflammation inhibited LH $\beta$ gene expression in the AP and reduced LH level in blood. A sevenfold LPS injection raises FSH concentration. The gene expression of GnRHR was reduced in the ovine AP only after a single injection of endotoxin. Our results suggest that there are important differences in the way how an acute and prolonged inflammation influence proinflammatory cytokines and their receptors gene expression in the AP of anestrous ewes, which could be reflected by differences in the AP secretory activity during these states.
\end{abstract}

Keywords: inflammation; cytokine; anterior pituitary; gonadotropins

\section{Introduction}

An acute and prolonged inflammation affects endocrine system functioning in numerous animal species, including sheep [1,2]. Circulating inflammatory mediators, such as interleukin (IL) $-1 \beta$, IL-6 and tumor necrosis factor (TNF $\alpha$ ), play an important role in the induction of endocrine disorders during inflammation. It was determined that these pro-inflammatory mediators might affect the reproductive process via the alteration of the hypothalamic-pituitary-gonadal axis activity [3-5]. This action of pro-inflammatory cytokines may occur both at the hypothalamic [6] and pituitary level [7]. However, the recent studies conducted on sheep suggest that an acute and prolonged inflammation may influence gonadotropins secretion in different ways. A single administration of 
endotoxin suppresses circulating concentration of luteinizing hormone (LH) in a number of species, including rats, sheep, cattle, and non-human primates $[1,8,9]$. There is no effect of an LPS injection on FSH plasma concentration in rats and sheep, while in sheep the gene expression of follicle-stimulating hormone (FSH) $\beta$ was increased $[6,8]$. On the other hand, the study with a prolonged administration of endotoxin showed that the plasma concentration of FSH grew up from second day in LPS-treated ewes, while the LH release stayed decreased [10]. On the other hand, a prolonged inflammation induced by LPS injection in primates (Rhesus Monkey) caused an increase in circulating concentration of both FSH and LH [11].

It is well proven that inflammation modulates the reproduction process affecting the GnRH secretion at the level of hypothalamus. It was described that an LPS-induced acute inflammation inhibited the LH release via suppression of the pulsatile secretion of $\mathrm{GnRH}$ in the hypothalamus of sheep [1]. The results of our previous study suggest that the reduction of GnRH secretion occurring during an immune/inflammatory challenge might result from the inhibition of this decapeptide synthesis at the level of its gene transcription in the preoptic area by centrally acting IL-1 $\beta$ [12]. However, a recent ex vivo study showed that proinflammatory cytokines may also influence LH secretion directly at the level of pituitary. It was found that IL-1 $\beta$ reduced GnRH-stimulated the LH secretion from the anterior pituitary (AP) explants [5], while IL-6 stimulated the LH release from pituitary explants [13]. The pro-inflammatory cytokines may act on the pituitary cells due to the existence of their corresponding receptors in cell membranes $[7,14,15]$. Our previous study showed that mRNA encoding proinflammatory cytokines could be transcribed directly in the pituitary [14]; therefore, the local expression of these mediators as well as their corresponding receptors could have a profound influence on the secretory activity of this gland especially during inflammatory states.

The aim of this study was to determine the influence of an acute and prolonged inflammation on the expression of genes encoding pro-inflammatory cytokines such as IL-1 $\beta$, IL-6, TNF $\alpha$ and their corresponding receptors, $\mathrm{LH}, \mathrm{FSH}$ and GnRH receptor in the AP and the circulating concentration of LH and FSH. The study was performed on blackhead ewes model because, in contrast to rodents, the sensitivity of sheep to the action of endotoxins is similar to humans. Therefore these animals are increasingly used in the studies on many diseases including sepsis, asthma pathogenesis, vaccine development and the optimization of drug delivery and surgical techniques [16,17].

\section{Results}

\subsection{Influence of Acute and Prolonged Inflammation on IL1B, IL1R1 and IL1R2 Gene Expression}

The expression of IL1 $\beta$ was stimulated $(p<0.05)$ by a single injection of LPS (Figure $1 \mathrm{~A})$. Moreover, the expression of mRNA for both types of IL-1 receptors (IL1R1 and IL1R2) is increased during an acute inflammation (Figure 1B,C). On the other side, a sevenfold injection of endotoxin caused no effect on IL1 $\beta$ mRNA expression (Figure 1A). There is also no difference in IL1R1 and IL1R2 gene expression during prolonged stress compared to the control group (Figure 1B,C). 

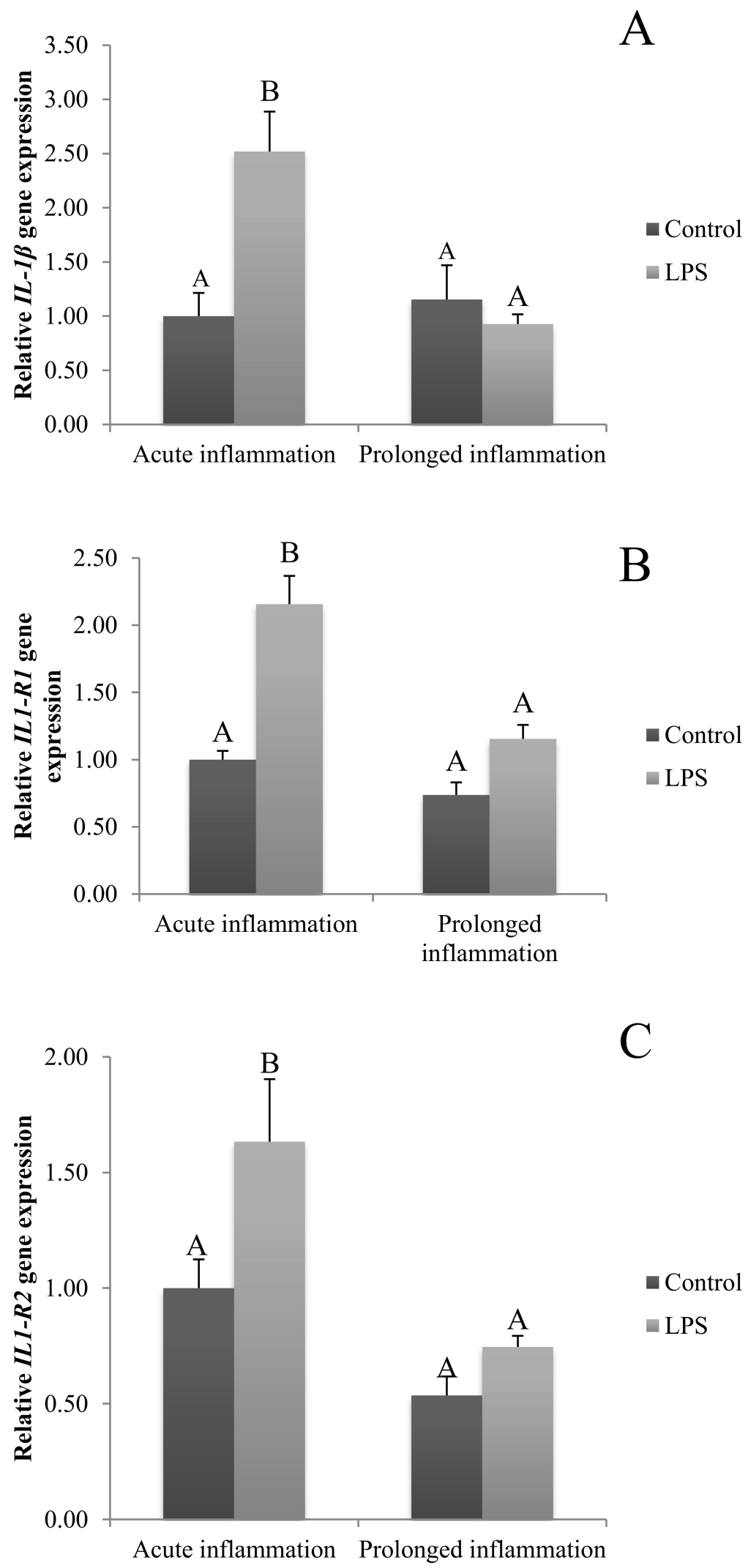

$\mathrm{C}$

- Control

- LPS

Figure 1. The effects of an acute and prolonged inflammation on the relative IL1 $\beta$ (A) and their receptors IL1R1 (B) and IL1R2 (C) mRNA levels in the AP normalized to the average value of three reference genes expression: actin beta (ACTB), glyceraldehyde 3-phosphate dehydrogenase (GAPDH), peptidylprolyl isomerase C (PPIC). The data are presented as a mean value \pm S.E.M.; Significantly according to the multiple analysis of variance followed by a Tuckey's post-hoc test $(p<0.05)$. ABC-bars with different letters vary. 


\subsection{Influence of Acute and Prolonged Inflammation on IL-6, IL-6R and IL-6ST Gene Expression}

A single LPS injection increased $(p<0.05)$ IL6 gene expression (Figure 2A). The level of IL6R (Figure 2B) and IL6ST (Figure 2C) mRNA expression was higher $(p<0.05)$ during an acute inflammation compared to the control group. The prolonged inflammation has no effect on IL6 mRNA expression (Figure 2A). However, a sevenfold LPS injection enhanced $(p<0.05)$ IL6R (Figure 2B) and IL6ST (Figure 2C) gene expression in comparison to the control group.
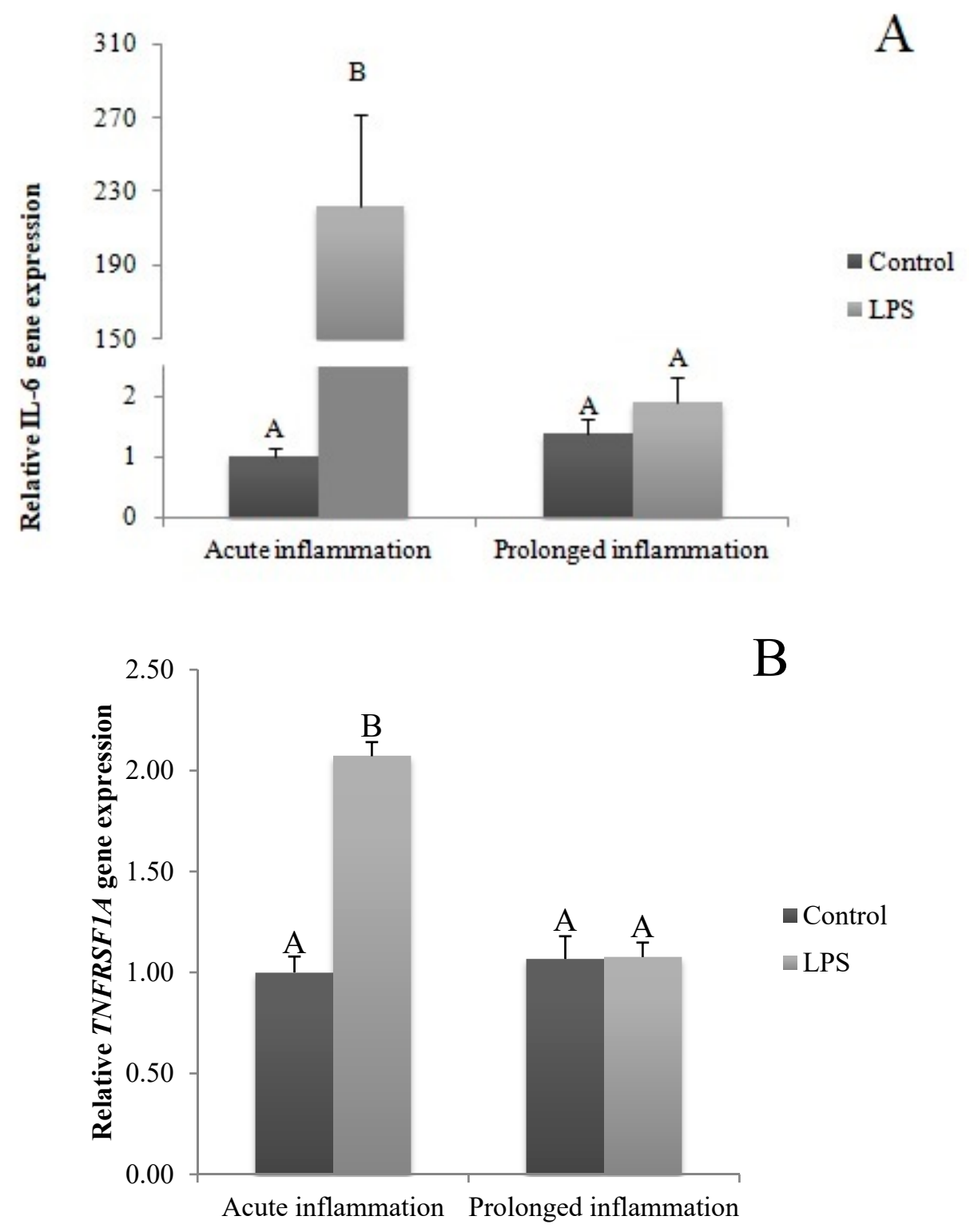

Figure 2. Cont. 


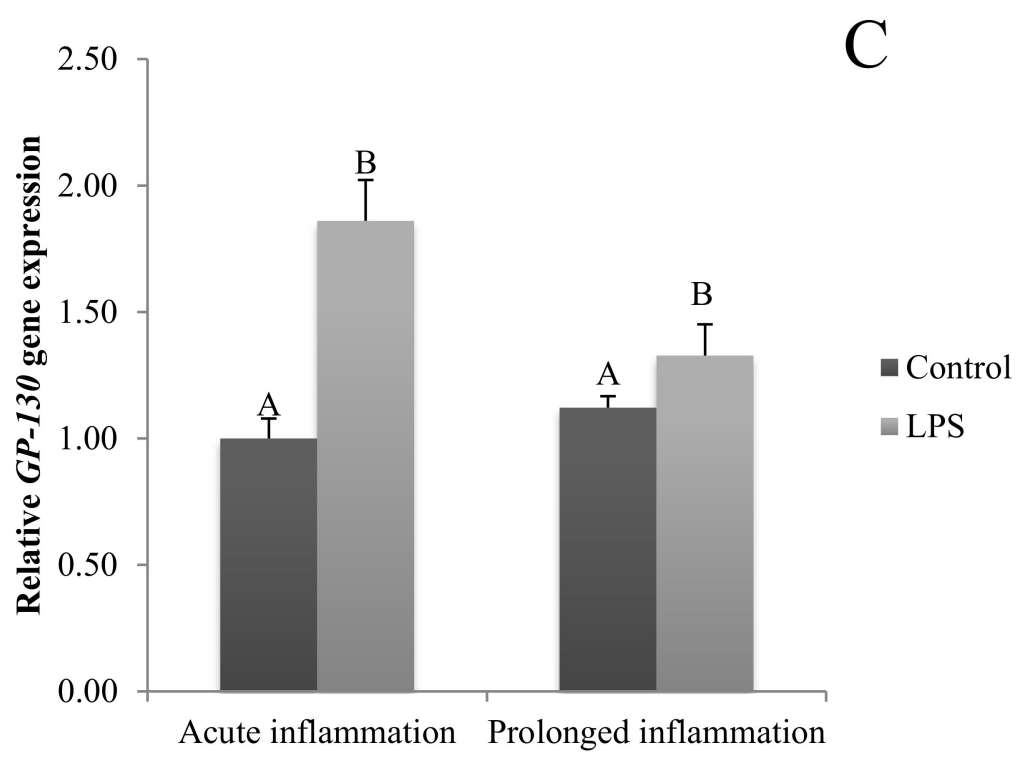

Figure 2. The effects of an acute and prolonged inflammation on the relative IL6 (A) and their receptors IL6R (B) and IL6ST (C) mRNA levels in the AP normalized to the average value of three reference genes expression: actin beta (ACTB), glyceraldehyde 3-phosphate dehydrogenase (GAPDH), peptidylprolyl isomerase C (PPIC). The data are presented as a mean value \pm S.E.M.; Significantly according to the multiple analysis of variance followed by a Tuckey's post-hoc test $(p<0.05)$. ABC-bars with different letters vary.

\subsection{Influence of Acute and Prolonged Inflammation on TNF, TNFRSF1A and TNFRSF1A Gene Expression}

The TNF $\alpha$ gene expression was stimulated $(p<0.05)$ during an acute inflammation (Figure 3A). Both TNF receptors (TNFRSF1A and TNFRSF1B) gene expression was enhanced $(p<0.05)$ also by a single endotoxin injection (Figure 3B,C). Sevenfold administration of an inflammatory factor enhanced $(p<0.05) \mathrm{TNF} \alpha$ gene expression (Figure 3A). Furthermore, this expression is stronger $(p<0.05)$ even in comparison to TNF $\alpha$ gene expression in the acute inflammation group. There is no effect of prolonged inflammation on TNFRSF1A (Figure 3B) and TNFRSF1B (Figure 3C) gene expression.

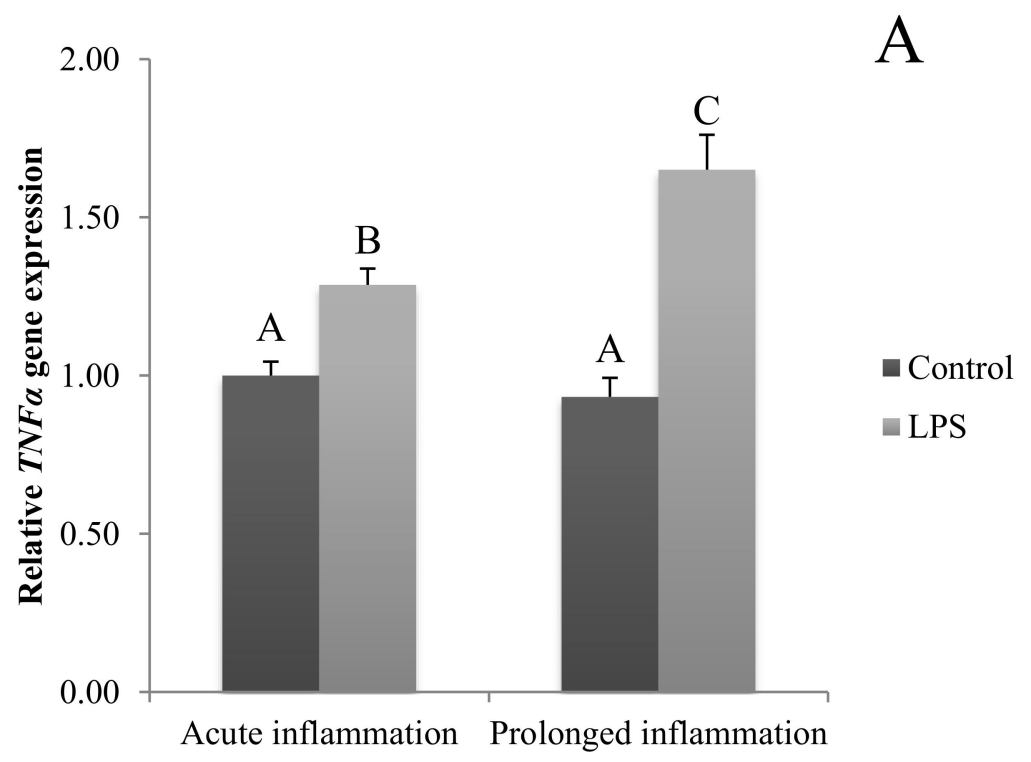

Figure 3. Cont. 

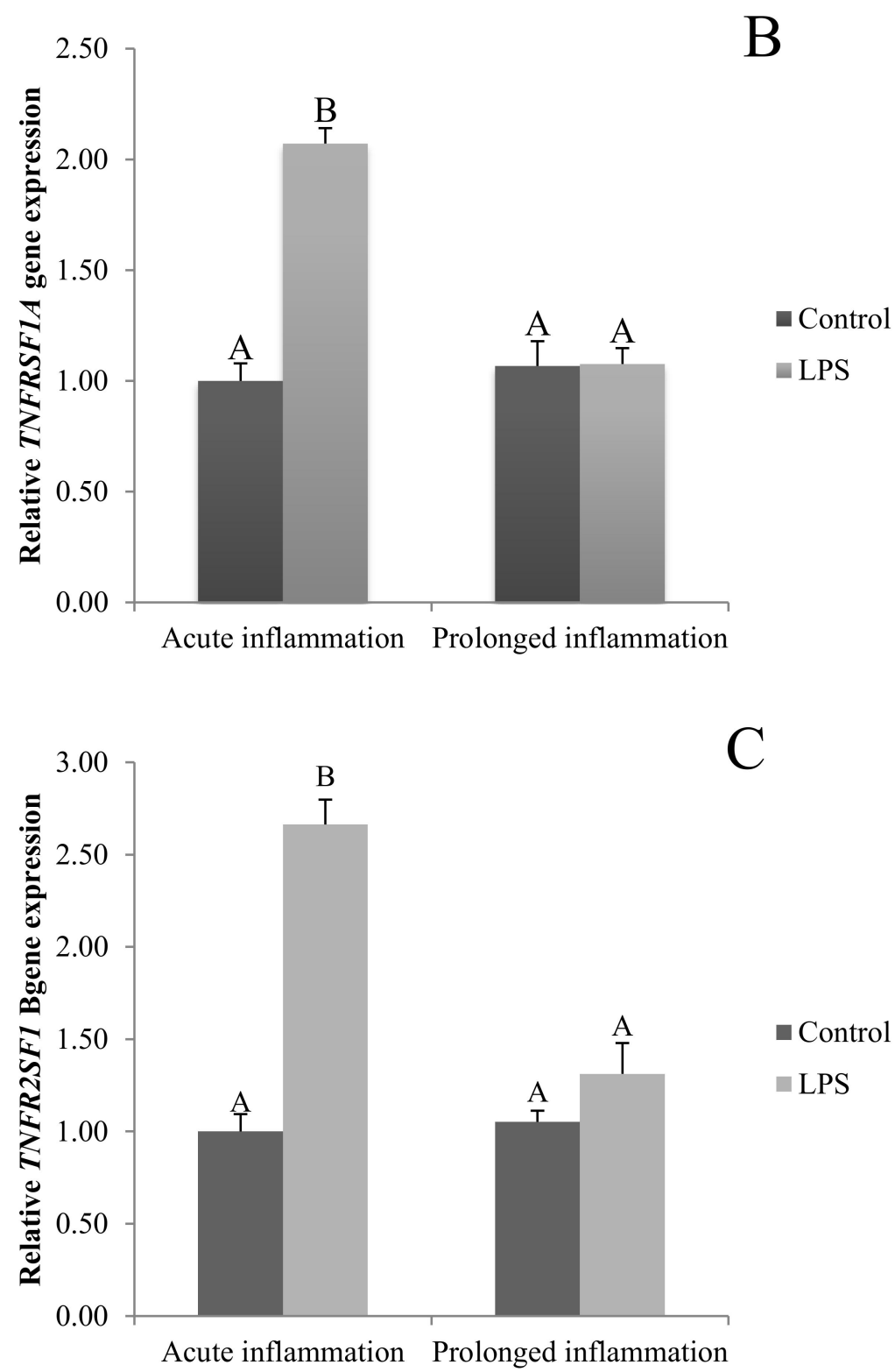

Figure 3. The effects of an acute and prolonged inflammation on the relative TNF $\alpha(\mathbf{A})$ and their receptors TNFRSF1A (B) and TNFRSF1B (C) mRNA levels in the AP normalized to the average value of three reference genes expression: actin beta (ACTB), glyceraldehyde 3-phosphate dehydrogenase $(\mathrm{GAPDH})$, peptidylprolyl isomerase C (PPIC). The data are presented as a mean value \pm S.E.M.; Significantly according to the multiple analysis of variance followed by a Tuckey's post-hoc test $(p<0.05)$. ABC-bars with different letters vary.

\subsection{Influence of Acute and Prolonged Inflammation on LH,$F S H \beta$ and GnRHR Gene Expression}

A single LPS injection inhibited $(p<0.05)$ both $L H \beta$ (Figure 4A) and GnRHR (Figure 4C). No effect of an acute inflammation was observed on FSH $\beta$ gene expression (Figure 4B). A sevenfold LSP administration resulted in the reduction $(p<0.05)$ of $L H \beta$ gene expression level. The level of $L H \beta$ gene expression was similar during the acute and prolonged inflammation. There was no effect of the prolonged inflammation of FSH $\beta$ (Figure 4B) and GnRHR (Figure 4C) gene expression. 

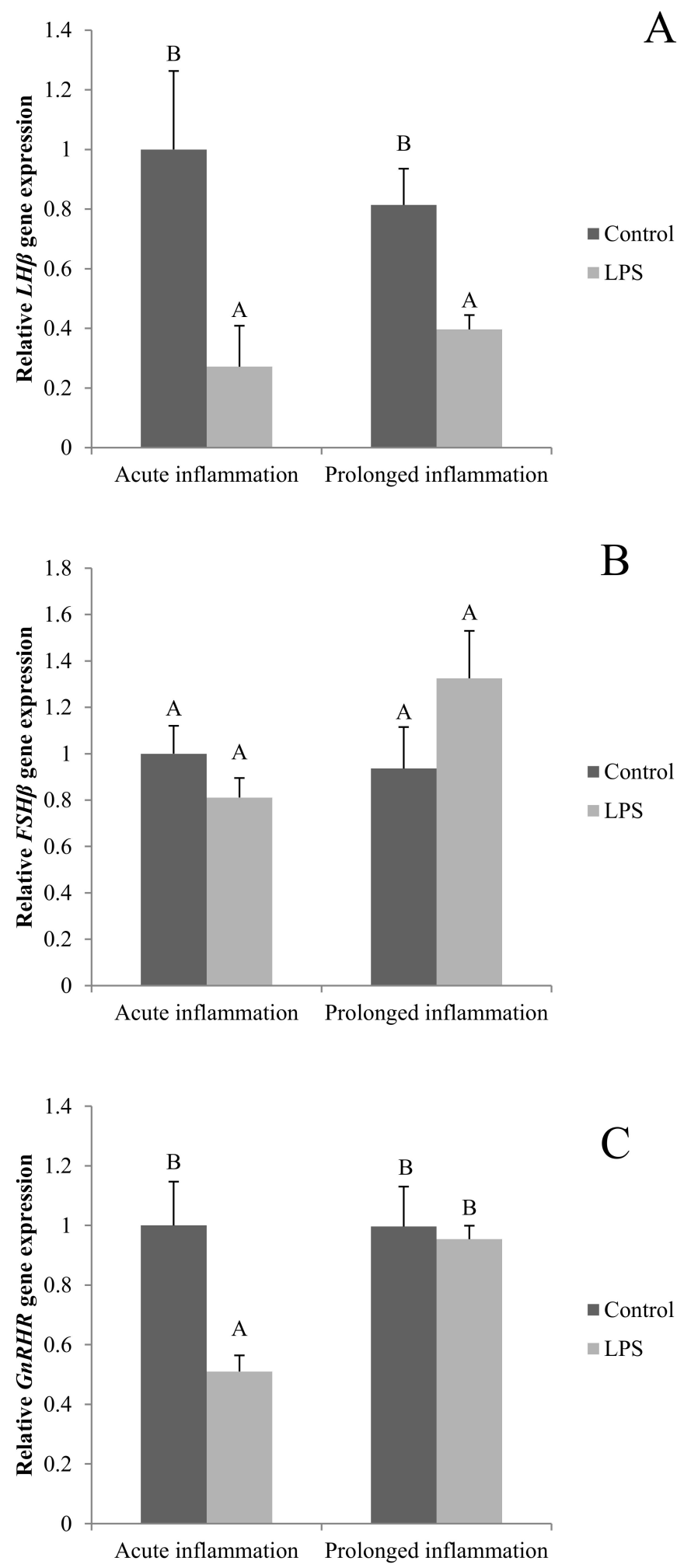

Figure 4. The effects of an acute and prolonged inflammation on the relative $L H \beta$ (A) $F S H \beta(\mathbf{B})$ and GnRHR (C) mRNA levels in the AP normalized to the average value of three reference genes expression: actin beta $(A C T B)$, glyceraldehyde 3-phosphate dehydrogenase $(G A P D H)$, peptidylprolyl isomerase $\mathrm{C}(P P I C)$. The data are presented as a mean value \pm S.E.M.; Significantly according to the multiple analysis of variance followed by a Tuckey's post-hoc test $(p<0.05)$. AB-bars with different letters vary. 


\subsection{Influence of Acute and Prolonged Inflammation on LH and FSH Concentration in Blood}

The blood concentration of LH was lower $(p<0.05)$ after both, a single and a sevenfold LPS injection. Additionally, the inhibitory effect of LPS was stronger $(p<0.05)$ during the prolonged inflammation (Figure 5A). There is no effect of single LPS treatment, while the sevenfold LPS injection raises $(p<0.05)$ the FSH concentration level (Figure 5B).
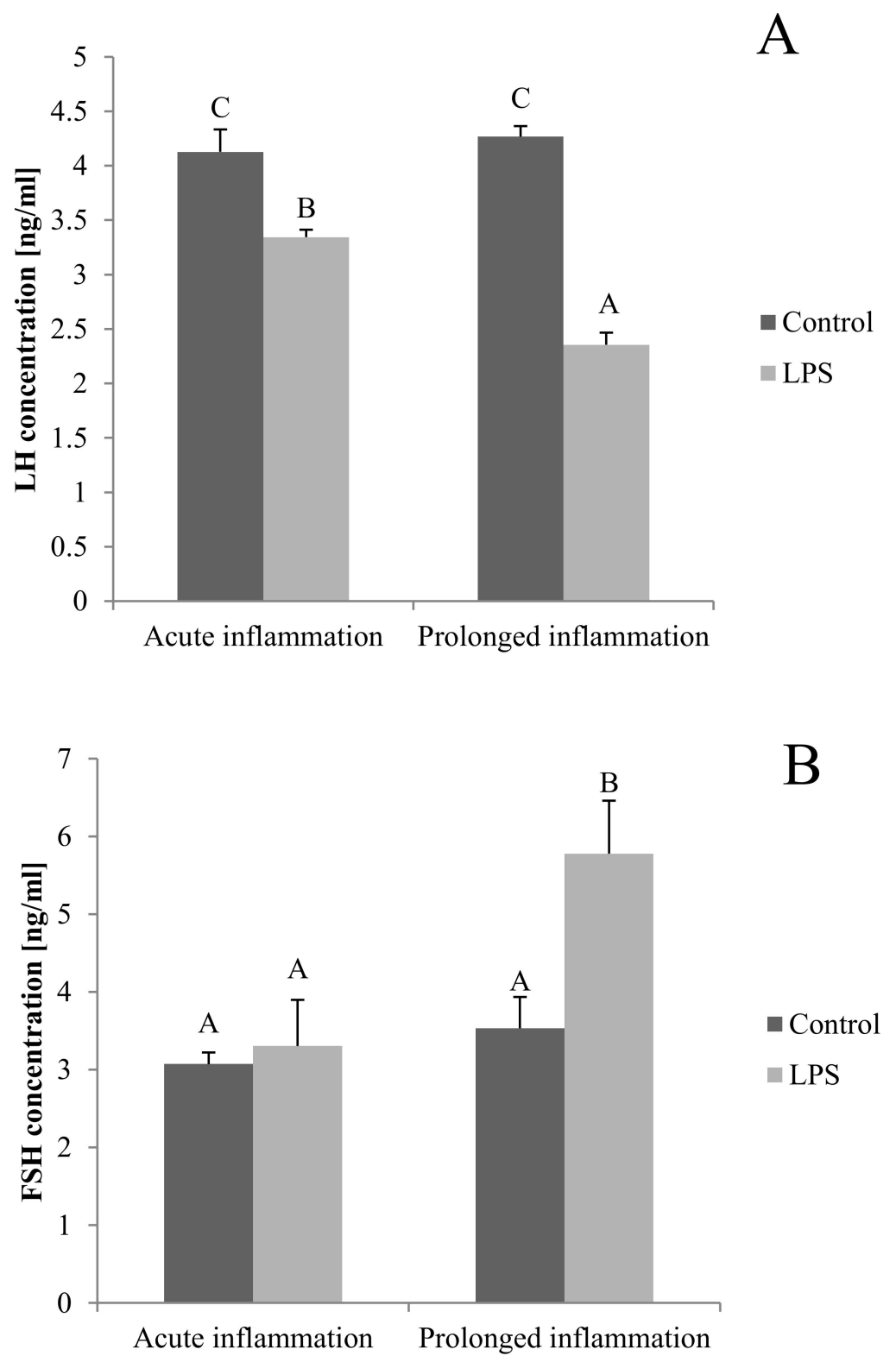

Figure 5. The effects of an acute and prolonged inflammation on the LH (A) and FSH (B) centration in blood. The data are presented as a mean value \pm S.E.M.; Significantly according to the multiple analysis of variance followed by a Tuckey's post-hoc test $(p<0.05)$. ABC-bars with different letters vary.

\section{Discussion}

Our study showed that mRNA encoding proinflammatory cytokines is transcribed in the significant amount in the ovine AP, both in the physiological state as well as during inflammation. This finding supports the results of our previous study showing the existence of nocturnal pro-inflammatory cytokine and their receptors gene expression in ovine Pars Tuberalis (PT) cells [14]. Moreover, the expression of interleukin in the pituitary had been previously reported in the study on the rat and mouse $[15,18,19]$. Studies on rats and mice AP showed that IL-1 $\beta$, IL- 6 and TNF $\alpha$ are secreted 
mainly by folliculo-stellate (FS) cells [20], moreover the in vitro study on this cells showed that folliculo-stellate cells are rich source of IL-6 and this cytokine is produced without an intentional stimulation [21]. On the other hand, the synthesis of IL1 mRNA was detected not only in FS cells but also in pituicytes and thyrotropes of rat [22]. Meanwhile, the study on human showed the expression of mRNA encoding proinflammatory cytokines in the pituitary tumor cells [7]. The expression of proinflammatory cytokines can be modulated by numerous factors, including cytokines themselves or LPS [23].

However, the majority of the studies analyzed only the effect of an acute exposure to LPS action on the pituitary cells. In 1993, Takao et. al., found that single LPS treatment enhanced IL-1 $\beta$ synthesis in mouse pituitary, spleen and testis, while the concentration of IL-1 $\beta$ in hypothalamus and hippocampus did not change after one LPS injection. In the second part of the experiment, the scientists determined if the LPS-induced increases in IL-1 $\beta$ concentration altered IL-1 receptors. It turned out that a double injection caused a significant decrease in [125I] IL-1 alpha binding using quantitative autoradiography in pituitary [15]. The study on mice also showed that the injection of LPS enhanced both: the serum level of $I L-1 \beta, I L-6$ and TNF $\alpha$ and the gene expression of these cytokines in the hypothalamus [24], pituitary and peripheral tissue [18]. Moreover, it was found that an intratracheal injection of LPS also upregulates IL-1 $\beta$ and TNF $\alpha$ expression in rat lung [25], IL-6 in rat [26] and mouse [27] liver.

Our study showed that there are significant differences between the effect of an acute and prolonged LPS-treatment on the gene expression of proinflammatory cytokines and their receptors in the ovine anterior pituitary. It was found that a single LPS injection increased the transcription of all examined cytokines, which is similar to other experiments conducted on sheep [28]. In contrast to acute inflammation when the gene expression of all examined cytokines was increased (the transcription of IL- 6 and IL- $1 \beta$ was increased more than TNF $\alpha$ ), prolonged administration of bacterial endotoxin did not influence $I L-1 \beta$ and $I L-6$ gene expression in the anterior pituitary. On the other hand, the prolonged LPS treatment significantly increased the gene expression of TNF $\alpha$ in the AP whereas the stimulatory effect of the acute LPS administration was on this gene expression was weaker. It is worth mentioning that the lack of a stimulatory effect of a prolonged inflammation on the gene expression of $I L-1 \beta$ and $I L-6$ in the pituitary differs from the previous observation made in other brain structure-hypothalamus. These experiment showed that a sevenfold injection of LPS increased the synthesis of $I L-1 \beta, I L-6$ and TNF $\alpha$ in ovine hypothalamus [29]. Moreover, in the hypothalamus the LPS-dependent induction of IL- 6 synthesis was stronger than in the case of $I L-1 \beta$ and TNF $\alpha$. These observations wew also supported by the study on mice analyzing the pattern of cytokine synthesis in the brain after a repetitive LPS injection. This study shows that the brain and serum cytokine and chemokine profiles differed in mice receiving a single LPS injection compared to multiple LPS injections. In a mouse brain, three injections of LPS elevated IL-1 $\alpha, I L-6$, and TNF $\alpha$ compared to controls and the values for a single LPS injection [30].

The obtained results suggest that a different response of the endocrine system during an acute and prolonged inflammation at least partially may result from the differences in the local synthesis of proinflammatory cytokines in the pituitary gland. Whereas during an acute inflammation the secretory activity of the pituitary may be dependent upon the local synthesis and action of all examined proinflammatory mediators, during a prolonged inflammation this modulatory action seems to be primarily mediated by TNF $\alpha$. It is well known that an acute and chronic inflammation is accompanied by an increased production of TNF $\alpha$ [31,32]. Experiments with the knock-in mice with a deletion that results in TNF overproduction, showed the development of chronic inflammatory arthritis and inflammatory bowel disease [33]. It is worth mentioning that the blockade of TNF $\alpha$ synthesis is considered to be an effective way to therapy of many disorders which are accompanied by the chronic inflammation $[32,34]$. Based on our findings it seems to be reasonable that a therapy focused on inhibiting TNF $\alpha$ synthesis could have some beneficial effect on the endocrine disorders which commonly accompany prolonged inflammatory states, such as reproduction disorders. 
$I L-1 \beta$ gene expression is commonly induced in the brain after LPS treatment. The regions of blood-cerebrospinal fluid barrier had an early and sustained induction of $I L-1 \beta$ gene expression, while regions of the brain lacking BBB are characterized by only an early increase of this gene expression. In the hypothalamus, a remarkable increase of $I L-1 \beta$ mRNA $6 \mathrm{~h}$ after an LPS injection was observed, while in the pituitary gland high levels of the induction of IL- $1 \beta$ mRNA in the posterior pituitary, with little $I L-1$ receptor agonist (ra), $I L-10$, or $I L-13$ gene expression was found. In contrast, in the AP it was found that a systemic inflammation induced IL-1ra mRNA in the levels that were much higher than those for IL-1 $\beta$ mRNA [35].

Specific receptors are needed for cytokines to properly affect cell functioning. In mice and human, two distinct types of IL-1 receptors (IL-1R) have been characterized. Most of the IL-1 signal is transmitted through IL-1R and IL-1R2 and may act as a suppressor of IL-1 $\beta$ biological activities by competing in binding with IL-1R1 on the cell surface [36]. IL-6 initially binds to the membrane bound, or non-signal-transducing IL-6R. The complex of IL-6 and IL-6R associates with the signal transducing membrane protein gp130, promoting its dimerization and the initiation of intracellular signaling $[37,38]$. Two distinct receptors are required to exert TNF bioactivity. It is considered that TNFR1 promotes inflammation and tissue degeneration, while TNFR2 mediates local homeostatic effects, such as cell endurance and tissue regeneration [31,39]. All those receptors are present in the pituitary gland [40]. Our earlier study showed that the transcripts encoding proinflammatory cytokines and their receptors were expressed in the PT. Moreover, the LPS administration during a long night caused a higher expression of IL6, TNF, IL6ST, TNFRSF1A and TNFRSF1B genes compared to that in the tissues collected during a short night. A similar influence of the photoperiod was also observed in the case of TNF $\alpha$ gene expression in the control animals. A higher level of TNF $\alpha$ gene expression during the long night was also observed in the control group of animals [14].

Our study also showed the expression of mRNA encoding proinflammatory cytokines receptors in the AP gland. This expression is different depending on the duration of the inflammatory signal. In our study only an acute inflammation induced the expression of both IL-1 receptors gene, while a prolonged inflammation did not affect this expression, in contrast to IL-6 receptors which are enhanced during an acute as well during prolonged inflammation. This may be due to the fact that $I L-1 \beta$ gene expression in AP is enhanced only in the acute inflammation, while $I L-6$ may be a part of an acute and prolonged inflammation. Despite the inflammation induced TNF expression during both type of inflammation, its receptors gene expression is enhanced only during the acute immune stress. It can be an effect of TNF specificity. As it was mentioned, this cytokine is significantly elevated during an autoimmunological disease $[33,41]$, so the constant level of receptor gene expression during prolonged inflammation may be to protect the cell from overstimulation.

It is well documented that an acute as well prolonged LPS administration influence gonadotropins secretion in sheep $[6,10]$. In the present study we demonstrated that inflammatory dependent changes in the gene expression of proinflammatory cytokines and their receptors are accompanied by the changes in the secretory activity of ovine AP. The reduction of LH secretion under an acute and prolonged immune stress was found. On the other hand, the FSH secretion was raised after a repeated LPS injection. It was previously reported that cytokines acting in an autocrine and paracrine ways in the pituitary, affect the hormone secretion and pituitary growth. IL-1 $\beta$, in dose-dependent manner, inhibits the growth of rat pituitary cells and this effect was reversed by IL-1 receptor agonist. Moreover, IL-1 $\beta$ stimulated most rat pituitary hormones secretion [40]. On the other hand, the picomolar concentration of IL-6 may enhance prolactin release, growth hormone $(\mathrm{GH})$ and LH from dispersed AP cells [42]. IL-6 stimulates GH release from rat hemipituitaries [43] and GH and prolactin release from lactosomatotrophic cells [44]. It has been stated that TNF blunts the release of adrenocorticotropic hormone (ACTH) and other pituitary hormones in response to hypothalamic factors in AP cells culture. TNF treatment of hemipituitaries increased ACTH, GH and thyroid-stimulating hormone (TSH) secretion, while prolactin secretion was not affected. However, those results were dose-dependent [40]. 
It is worth mentioning that the reduction of LH secretion during an acute and prolonged inflammation could result from the suppression of $\mathrm{GnRH}$ secretion in the hypothalamus. Our previous study showed that both the acute [45,46] and prolonged [47] inflammation reduced GnRH secretion in the hypothalamus of ewes. Moreover, the suppression of LH secretion during the acute inflammation could result from a reduced expression of GnRHR in the AP. The amount of GnRHR determining the ability and storage strength of the pituitary gonadotropes in response to GnRH [48]. It was previously found that during inflammation the pituitary sensitivity to GnRH stimulation [9] and the expression of GnRHR in ewes were suppressed [49,50]. It is believed that the lower GnRHR gene expression in the pituitary during an immune/inflammatory challenge is mainly due to the lower secretion of the hypothalamic GnRH [1,45-47], which is one of the most important regulator of its own receptor expression.

Although inflammation interrupts $\mathrm{GnRH} / \mathrm{LH}$ regulation, it has been confirmed that LPS injection may elevate the FSH concentration [51]. Our results show that prolonged inflammation caused a higher blood concentration of FSH, which is similar with our previous study in which the stimulatory effect of LPS was observed from the second injection [10].

\section{Materials and Methods}

\subsection{Animals and Experimental Design}

The experiments were carried out on Blackhead ewes $(n=24)$ during long day (LD) $(8: 16$, June). The animals were maintained indoors in individual pens and were exposed to natural daylight present at $52^{\circ} \mathrm{N}$ latitude and $21^{\circ} \mathrm{E}$ longitude. The ewes were maintained in good conditions, i.e., their body condition was estimated at 3 in a five-point scale [52] and the animals were acclimated to the experimental conditions for one month. The ewes had constant visual contact with each other in order to avoid isolation stress. The animals were fed a constant diet of commercial concentrates with hay and water available ad libitum, according to the recommendations proposed by the National Research Institute of Animal Production for adult ewes [53].

The experiments were carried out on 3 years old Blackhead ewes $(n=24)$ from the same herd, during long day (LD) (8:16, June). During the first experiment, an acute stress was induced by single injection into the jugular vein, an appropriate volume of LPS from E. coli 055:B5 (400 ng• $\left.\mathrm{kg}^{-1}\right)$ (Sigma-Aldrich, St Louis, MO, USA) dissolved in saline $(0.9 \%$ w/v NaCl) (Baxter, Deerfield, IL, USA). In the second group, a prolonged inflammation was induced by a sevenfold i.v. injection of LPS (one injection per day, at the same hour). The maximum volume of an injected LPS solution (10 mg・L-1) has never exceeded $2.5 \mathrm{~mL}$. The control group received the same volume of $\mathrm{NaCl}$ (based on their body weight). The treatments was always administered at 9:00 a.m. The scheme of the conducted experiment is shown in Figure 6. The efficiency of the LPS treatment to induce an inflammatory response in the animal was estimated based on the measurement of the body temperature an hour after the treatment. Jugular blood samples were taken for measurement of LH 15-min before the euthanasia by decapitation which took place three hours after the LPS or saline injection. The brain was immediately removed from the skull, and the AP was dissected, immediately frozen in liquid nitrogen and stored at $-80^{\circ} \mathrm{C}$ until further assay.

All procedures on animals were performed with the consent of the 3rd Local Ethical Commission of Warsaw University of Life Sciences-SGGW (Warsaw, Poland; authorization no. 43/2011 and 56/2013). 


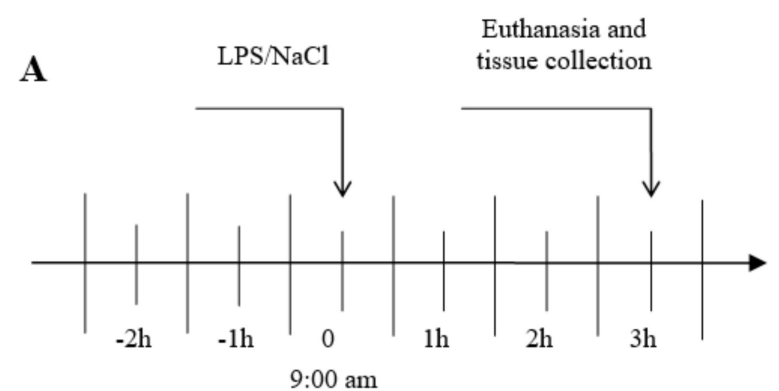

B

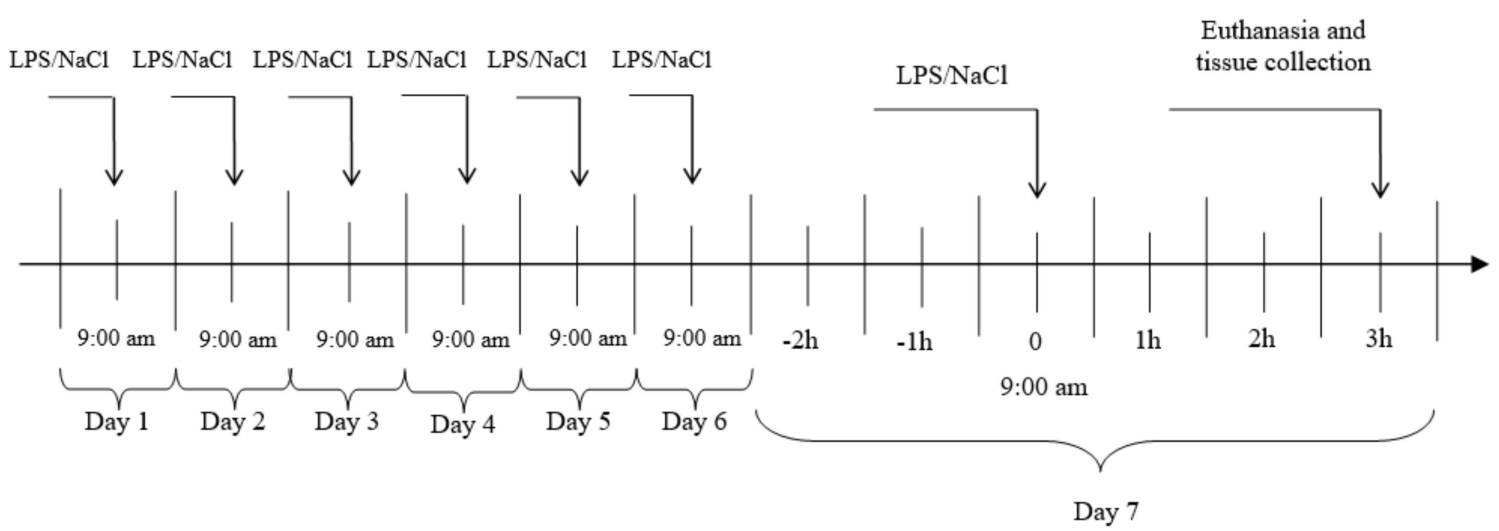

Figure 6. General procedure of experiment. A- Acute inflammation, B- prolonged inflammation, LPSlipopolisaccaride $\mathrm{S}$ from E. coli 055:B5 in $400 \mathrm{ng} \bullet \mathrm{kg}^{-1}$ dose.

\subsection{Determination of the Relative Gene Expression}

Total RNA from the collected AP was isolated using the NucleoSpin ${ }^{\circledR}$ RNA kit (MACHEREY-NAGEL $\mathrm{GmbH}$ and Co, Düren, Germany). Half a tissue of AP was homogenized using a TissueLyser (Qiagen, Hilden, Germany) and then all isolation steps were conducted in accordance with the manufacturer's instruction. The purity and concentration of the isolated RNA were quantified spectrophotometrically with the use of NanoDrop 1000 instrument (Thermo Fisher Scientific, Waltham, MA, USA). The integrity of the isolated RNA was confirmed by electrophoresis with the use of $1 \%$ agarose gel stained with ethidium bromide. The Maxima ${ }^{\mathrm{TM}}$ First Strand cDNA Synthesis Kit for RT-qPCR (Thermo Fisher Scientific) was used to perform cDNA synthesis. As a starting material for cDNA synthesis $2 \mu \mathrm{g}$ of total RNA were used. Real-Time RT-PCR was carried out with the use of the HOT FIREPol EvaGreen ${ }^{\circledR}$ qPCR Mix Plus (Solis BioDyne, Tartu, Estonia) and HPLC-grade oligonucleotide primers (Genomed, Warsaw, Poland) (Table 1). The reactions were run on Rotor-Gene q MDx instrument (Qiagen, Hilden, Germany). The specificity of the amplification was confirmed by a final melting curve analysis. The relative gene expression was calculated using the comparative quantification option (Rasmussen, 2001) of the Rotor-Gene q Series software 1.7. (Qiagen). To obtain the normalized results, the expression of the examined genes was calculated in relation to the average value of three reference genes expression: actin beta $(A C T B)$, glyceraldehyde 3-phosphate dehydrogenase $(G A P D H)$, peptidylprolyl isomerase $C$ (PPIC). The mean expression of these three housekeeping genes was used to normalize the expression of the analysed genes. The results are presented in arbitrary units, as the ratio of the target gene expression to the mean expression of the housekeeping genes. 
Table 1. All genes analyzed by real-time PCR are listed with their full names and abbreviations.

\begin{tabular}{|c|c|c|c|c|c|}
\hline GenBank Acc. No. & Gene & $\begin{array}{l}\text { Amplicon Size } \\
\text { [bp] }\end{array}$ & Forward/ Reverse & $\begin{array}{l}\text { Sequence } \\
5^{\prime} \rightarrow 3^{\prime}\end{array}$ & References \\
\hline \multirow{2}{*}{ NM_001034034 } & \multirow{2}{*}{$\begin{array}{l}\text { GAPDH } \\
\text { glyceraldehyde-3-phosphate dehydrogenase }\end{array}$} & \multirow{2}{*}{134} & forward & AGAAGGCTGGGGCTCACT & \multirow{2}{*}{ [46] } \\
\hline & & & reverse & GGCATTGCTGACAATCTTGA & \\
\hline \multirow{2}{*}{ U39357 } & \multirow{2}{*}{$\begin{array}{c}A C T B \\
\text { beta actin }\end{array}$} & \multirow{2}{*}{168} & forward & СTTCCTTCCTGGGCATGG & \multirow{2}{*}{ [46] } \\
\hline & & & reverse & GGGCAGTGATCTCTTTCTGC & \\
\hline \multirow{2}{*}{ NM_001076910 } & \multirow{2}{*}{$\begin{array}{c}\text { PPIC } \\
\text { Cyclophilin C }\end{array}$} & \multirow{2}{*}{145} & forward & TGGCACTGGTGGTATAAGCA & \multirow{2}{*}{ [46] } \\
\hline & & & reverse & GGGCTTGGTCAAGGTGATAA & \\
\hline \multirow{2}{*}{ X54796.1 } & \multirow{2}{*}{$\begin{array}{c}\text { IL1B } \\
\text { interleukin } 1 \text { beta }\end{array}$} & \multirow{2}{*}{137} & forward & CAGCCGTGCAGTCAGTAAAA & \multirow{2}{*}{ [46] } \\
\hline & & & reverse & GAAGCTCATGCAGAACACCA & \\
\hline \multirow{2}{*}{ NM_001206735.1 } & \multirow{2}{*}{$\begin{array}{c}\text { IL1R1 } \\
\text { Interleukin } 1 \text { receptor, type I }\end{array}$} & \multirow{2}{*}{124} & forward & GGGAAGGGTCCACCTGTAAC & \multirow{2}{*}{ [46] } \\
\hline & & & reverse & ACAATGCTTTCCCCAACGTA & \\
\hline \multirow{2}{*}{ NM_001046210.1 } & \multirow{2}{*}{$\begin{array}{l}I L 1 R 2 \\
\text { interleukin } 1 \text { receptor, type II }\end{array}$} & \multirow{2}{*}{161} & forward & CGCCAGGCATACTCAGAAA & \multirow{2}{*}{ [46] } \\
\hline & & & reverse & GAGAACGTGGCAGCTTCTTT & \\
\hline \multirow{2}{*}{ NM_001009392.1 } & \multirow{2}{*}{$\begin{array}{c}\text { IL6 } \\
\text { Interleukin } 6\end{array}$} & \multirow{2}{*}{165} & forward & GTTCAATCAGGCGATTTGCT & \multirow{2}{*}{ [46] } \\
\hline & & & reverse & CCTGCGATCTTTTCCTTCAG & \\
\hline \multirow{2}{*}{ NM_001110785 } & \multirow{2}{*}{$\begin{array}{c}I L 6 R \\
\text { Interleukin } 6 \text { receptor }\end{array}$} & \multirow{2}{*}{149} & forward & TCAGCGACTCCGGAAACTAT & {$[46]$} \\
\hline & & & reverse & CCGAGGACTCCACTCACAAT & \\
\hline XM 004016974 & IL6ST & 139 & forward & GGCTTGCCTCCTGAAAAACC & [14] \\
\hline & glycoprotein 130 & 10 & reverse & АCTTCTCTGTTGCCCACTCAG & \\
\hline NM_001024860 & $T N F$ & 153 & forward & CAAATAACAAGCCGGTAGCC & [46] \\
\hline & Tumor necrosis factor & & reverse & AGATGAGGTAAAGCCCGTCA & \\
\hline NM_174674 & TNFRSF1A & 137 & forward & AGGTGCCGGGATGAAATGTT & [46] \\
\hline $10101-1 / 40 / 4$ & Tumor necrosis factor receptor, type 1 & & reverse & CAGAGGCTGCAGTTCAGACA & \\
\hline NM 001040490 & TNFRSF1B & 122 & forward & АССТТСТТССТССТСССААА & [46] \\
\hline & Tumor necrosis factor receptor, type 2 & & reverse & AGAAGCAGACCCAATGCTGT & \\
\hline NM 001009397 & GnRHR & 150 & forward & TCTTTGCTGGACCACAGTTAT & [47] \\
\hline & Gonadotropin releasing hormone receptor & & reverse & GGCAGCTGAAGGTGAAAAAG & \\
\hline X52488 & $L H \beta$ & 184 & forward & AGATGCTCCAGGGACTGCT & [47] \\
\hline & Luteinizing hormone & & reverse & TGCTTCATGCTGAGGCAGTA & \\
\hline$X 15493$ & $F S H \beta$ & 131 & forward & TATTGCTACACCCGGGACTT & [47] \\
\hline & Follicle-stimulating hormone & & reverse & TACAGGGAGTCTGCATGGTG & \\
\hline
\end{tabular}




\section{Conclusions}

In conclusion, this study showed that an acute and prolonged inflammation differently influences the gene expression of pro-inflammatory cytokines and their receptors in the AP of ewes. Our results suggest that during an acute inflammation the secretory activity of the pituitary may be influenced by locally synthesized IL- $1 \beta$, IL- 6 and TNF- $\alpha$, whereas during a prolonged inflammation only the local transcription of TNF $\alpha$ is increased in this gland. In parallel with the changes in cytokines gene expression, we observed an influence in the acute and prolonged LPS treatment on gonadotropins secretion. Both the acute and prolonged inflammation, inhibited LH secretion, while only the prolonged LPS treatment influenced FSH secretion. Our results suggest that there are important differences in the way how an acute and prolonged inflammation influence proinflammatory cytokines and their receptors gene expression in the AP of anestrous ewes, which could be reflected by differences in AP secretory activity during these states. Due to the potential of proinflammatory cytokines to disturbing the secretory activity of the pituitary gland, the therapies targeted on the suppression on their local synthesis in the pituitary could have some beneficial effect during the treatment of endocrine disorders which accompany the inflammatory states; however, this requires future detailed studies.

Author Contributions: Conceptualization, K.W., A.P.H., D.T.-Z.; methodology, K.W., M.W., A.K.; formal analysis, K.W., A.P.H.; writing—original draft preparation, K.W.; writing—review and editing, A.P.H., D.T.-Z. All authors have read and agreed to the published version of the manuscript.

Funding: The research was funding by the "grant for young scientists" of the Ministry of Science and Higher Education obtained in the first edition of the "Grant for start" competition in the Institute

Conflicts of Interest: The authors declare no conflict of interest.

\section{Abbreviations}

$\begin{array}{ll}\text { ACTH } & \text { Adrenocorticotropic hormone } \\ \text { AP } & \text { Anterior pituitary } \\ \text { FS } & \text { Folliculo-stellate cells } \\ \text { FSH } & \text { Follicle-stimulating hormone } \\ \text { GH } & \text { Growth hormone } \\ \text { GnRH } & \text { Gonadotropin-releasing hormone } \\ \text { IL } & \text { Interleukin } \\ \text { LH } & \text { Luteinizing hormone } \\ \text { LPS } & \text { Lipopolisaccaride S } \\ \text { TNF } & \text { Tumor necrosis factor } \\ \text { TSH } & \text { Thyroid-stimulating hormone } \\ \text { PT } & \text { Pars Tuberalis }\end{array}$

\section{References}

1. Daniel, J.A.; Abrams, M.S.; de Souza, L.; Wagner, C.G.; Whitlock, B.K.; Sartin, J.L. Endotoxin inhibition of luteinizing hormone in sheep. Domest. Anim. Endocrinol. 2003, 25, 13-19. [CrossRef]

2. Danek, J.; Żurek, U. Changes in Domestic Animals after Endotoxin Administration a Review. Ann. Anim. Sci. 2014, 14, 479-489. [CrossRef]

3. Igaz, P.; Salvi, R.; Rey, J.-P.; Glauser, M.; Pralong, F.P.; Gaillard, R.C. Effects of Cytokines on Gonadotropin-Releasing Hormone (GnRH) Gene Expression in Primary Hypothalamic Neurons and in GnRH Neurons Immortalized Conditionally. Endocrinology 2006, 147, 1037-1043. [CrossRef] [PubMed]

4. Yoo, M.-J.; Nishihara, M.; Takahashi, M. Involvement of Prostaglandins in Suppression of Gonadotropin-Releasing Hormone Pulse Generator Activity by Tumor Necrosis Factor- $\alpha$. J. Reprod. Dev. 1997, 43, 181-187. [CrossRef]

5. Herman, A.P.; Krawczyńska, A.; Bochenek, J.; Dobek, E.; Herman, A.; Tomaszewska-Zaremba, D. LPS-Induced Inflammation Potentiates the IL-1-Mediated Reduction of LH Secretion from the Anterior Pituitary Explants. Clin. Dev. Immunol. 2013, 2013, 926937. [CrossRef] 
6. Herman, A.; Romanowicz, K.; Tomaszewska-Zaremba, D. Effect of LPS on Reproductive System at the Level of the Pituitary of Anestrous Ewes: Effect of LPS on Reproductive System at the Pituitary Level. Reprod. Domest. Anim. 2010, 45, e351-e359. [CrossRef]

7. Tsagarakis, S. The role of cytokines in the normal and neoplastic pituitary. Crit. Rev. Oncol. Hematol. 1998, 28, 73-90. [CrossRef]

8. Refojo, D.; Arias, P.; Moguilevsky, J.A.; Feleder, C. Effect of Bacterial Endotoxin on in vivo Pulsatile Gonadotropin Secretion in Adult Male Rats. Neuroendocrinology 1998, 67, 275-281. [CrossRef]

9. Williams, C.Y.; Harris, T.G.; Battaglia, D.F.; Viguie, C.; Karsch, F.J. Endotoxin Inhibits Pituitary Responsiveness to Gonadotropin-Releasing Hormone. Endocrinology 2001, 142, 8. [CrossRef]

10. Herman, A.; Kopycińska, K.; Krawczyńska, A.; Romanowicz, K.; Tomaszewska-Zaremba, D. The effect of repeated endotoxin injections on gonadotropin secretion in ewes. J. Anim. Feed Sci. 2014, 23, 217-221. [CrossRef]

11. Xiao, E.; Xia-Zhang, L.; Barth, A.; Zhu, J.; Ferin, M. Stress and the Menstrual Cycle: Relevance of Cycle Quality in the Short- and Long-Term Response to a 5-Day Endotoxin Challenge during the Follicular Phase in the Rhesus Monkey. J. Clin. Endocrinol. Metab. 1998, 83, 7. [CrossRef]

12. Herman, A.; Misztal, T.; Romanowicz, K.; Tomaszewska-Zaremba, D. Central Injection of Exogenous IL-1 $\beta$ in the Control Activities of Hypothalamic-Pituitary-Gonadal Axis in Anestrous Ewes: IL-1 $\beta$ Modulates the HPG Axis in Ewes. Reprod. Domest. Anim. 2012, 47, 44-52. [CrossRef] [PubMed]

13. Spangelo, B.L.; Judd, A.M.; Isakson, P.C.; Macleod, R.M. Interleukin-6 stimulates anterior pituitary hormone release in vitro. Endocrinology 1989, 125, 575-577. [CrossRef]

14. Król, K.; Tomaszewska-Zaremba, D.; Herman, A. Photoperiod-dependent effect of inflammation on nocturnal gene expression of proinflammatory cytokines and their receptors in pars tuberalis of ewe. J. Anim. Feed Sci. 2016, 25, 3-11. [CrossRef]

15. Takao, T.; Culp, S.G.; De Souza, E.B. Reciprocal modulation of interleukin-1 beta (IL-1 beta) and IL-1 receptors by lipopolysaccharide (endotoxin) treatment in the mouse brain-endocrine-immune axis. Endocrinology 1993, 132, 1497-1504. [CrossRef]

16. Scheerlinck, J.-P.Y.; Snibson, K.J.; Bowles, V.M.; Sutton, P. Biomedical applications of sheep models: From asthma to vaccines. Trends Biotechnol. 2008, 26, 259-266. [CrossRef] [PubMed]

17. Entrican, G.; Wattegedera, S.R.; Griffiths, D.J. Exploiting ovine immunology to improve the relevance of biomedical models. Mol. Immunol. 2015, 66, 68-77. [CrossRef]

18. Pitossi, F.; del Rey, A.; Kabiersch, A.; Besedovsky, H. Induction of cytokine transcripts in the central nervous system and pituitary following peripheral administration of endotoxin to mice. J. Neurosci. Res. 1997, 48, 287-298. [CrossRef]

19. Whiteside, M.; Quan, N.; Herkenharn, M. Induction of Pituitary Cytokine Transcripts by Peripheral Lipopolysaccharide. J. Neuroendocrinol. 1999, 11, 115-120. [CrossRef]

20. Jovanović, I.; Ugrenović, S.; Ljubomirović, M.; Vasović, L.; Čukuranović, R.; Stefanović, V. Folliculo-stellate cells-Potential mediators of the inflammaging-induced hyperactivity of the hypothalamic-pituitary-adrenal axis in healthy elderly individuals. Med. Hypotheses 2014, 83, 501-505. [CrossRef]

21. Vankelecom, H.; Carmeliet, P.; Van Damme, J.; Billiau, A.; Denef, C. Production of Interleukin-6 by Folliculo-Stellate Cells of the Anterior Pituitary Gland in a Histiotypic Cell Aggregate Culture System. Neuroendocrinology 1989, 49, 102-106. [CrossRef] [PubMed]

22. Koenig, J.I.; Snow, K.; Clark, B.D.; Toni, R.; Cannon, J.G.; Shaw, A.R.; Dinarello, C.A.; Reichlin, S.; Lee, S.L.; Lecha, R.M. Intrinsic Pituitary Interleukin-1 $\beta$ Is Induced by Bacterial Lipopolysaccharide. Endocrinology 1990, 126, 3053-3058. [CrossRef] [PubMed]

23. Gabay, C.; Kushner, I. Acute-phase proteins and other systemic responses to inflammation. N. Engl. J. Med. 1999, 340, 448-454. [CrossRef] [PubMed]

24. Skelly, D.T.; Hennessy, E.; Dansereau, M.-A.; Cunningham, C. A Systematic Analysis of the Peripheral and CNS Effects of Systemic LPS, IL-1B, TNF- $\alpha$ and IL-6 Challenges in C57BL/6 Mice. PLoS ONE 2013, 8, e69123. [CrossRef]

25. Ulich, T.R.; Watson, L.R.; Guo, K.; Wang, P.; Thang, H. The Intratracheal Administration of Endotoxin and Cytokines. Am. J. Pathol. 1991, 138, 12. [CrossRef]

26. Geisterfer, M.; Richards, C.; Baumann, M.; Fey, G.; Gywnne, D.; Gauldie, J. Regulation of IL-6 and the hepatic IL-6 receptor in acute inflammation in vivo. Cytokine 1993, 5, 1-7. [CrossRef] 
27. Li, L.; Duan, C.; Zhao, Y.; Zhang, X.; Yin, H.; Wang, T.; Huang, C.; Liu, S.; Yang, S.; Li, X. Preventive effects of interleukin-6 in lipopolysaccharide/ d -galactosamine induced acute liver injury via regulating inflammatory response in hepatic macrophages. Int. Immunopharmacol. 2017, 51, 99-106. [CrossRef]

28. Wójcik, M.; Herman, A.P.; Zieba, D.A.; Krawczyńska, A. The Impact of Photoperiod on the Leptin Sensitivity and Course of Inflammation in the Anterior Pituitary. IJMS 2020, 21, 4153. [CrossRef]

29. Herman, A.P.; Krawczyńska, A.; Bochenek, J.; Antushevich, H.; Herman, A.; Tomaszewska-Zaremba, D. Peripheral Injection of SB203580 Inhibits the Inflammatory-Dependent Synthesis of Proinflammatory Cytokines in the Hypothalamus. Biomed. Res. Int. 2014, 2014, 1-10. [CrossRef]

30. Erickson, M.A.; Banks, W.A. Cytokine and chemokine responses in serum and brain after single and repeated injections of lipopolysaccharide: Multiplex quantification with path analysis. Brain Behav. Immun. 2011, 25, 1637-1648. [CrossRef]

31. Kalliolias, G.D.; Ivashkiv, L.B. TNF biology, pathogenic mechanisms and emerging therapeutic strategies. Nat. Rev. Rheumatol. 2016, 12, 49-62. [CrossRef] [PubMed]

32. Kaplan, N.M.; Palmer, B.F.; Reimold, A.M. New Indications for Treatment of Chronic Inflammation by TNF- $\alpha$ Blockade. Am. J. Med. Sci. 2003, 325, 75-92. [CrossRef] [PubMed]

33. Kontoyiannis, D.; Pasparakis, M.; Pizarro, T.T.; Cominelli, F.; Kollias, G. Impaired On/Off Regulation of TNF Biosynthesis in Mice Lacking TNF AU-Rich Elements. Immunity 1999, 10, 387-398. [CrossRef]

34. Wong, M.; Ziring, D.; Korin, Y.; Desai, S.; Kim, S.; Lin, J.; Gjertson, D.; Braun, J.; Reed, E.; Singh, R.R. $\mathrm{TNF} \alpha$ blockade in human diseases: Mechanisms and future directions. Clin. Immunol. 2008, 126, 121-136. [CrossRef]

35. Wong, M.-L.; Bongiorno, P.B.; Rettori, V.; McCann, S.M.; Licinio, J. Interleukin (IL) 1, IL-1 receptor antagonist, IL-10, and IL-13 gene expression in the central nervous system and anterior pituitary during systemic inflammation: Pathophysiological implications. Proc. Natl. Acad. Sci. USA 1997, 94, 227-232. [CrossRef] [PubMed]

36. Kuno, K.; Matsushima, K. The IL-1 receptor signaling pathway. J. Leukoc. Biol. 1994, 56, 542-547. [CrossRef]

37. Scheller, J.; Garbers, C.; Rose-John, S. Interleukin-6: From basic biology to selective blockade of pro-inflammatory activities. Semin. Immunol. 2014, 26, 2-12. [CrossRef]

38. Rose-John, S. Interleukin-6 biology is coordinated by membrane-bound and soluble receptors: Role in inflammation and cancer. J. Leukoc. Biol. 2006, 80, 227-236. [CrossRef]

39. Probert, L. TNF and its receptors in the CNS: The essential, the desirable and the deleterious effects. Neuroscience 2015, 302, 2-22. [CrossRef]

40. Haedo, M.R.; Gerez, J.; Fuertes, M.; Giacomini, D.; Páez-Pereda, M.; Labeur, M.; Renner, U.; Stalla, G.K.; Arzt, E. Regulation of pituitary function by cytokines. Horm. Res. 2009, 72, 266-274. [CrossRef]

41. Rogoveanu, O.; Calina, D.; Cucu, M.; Burada, F.; Docea, A.; Sosoi, S.; Stefan, E.; Ioana, M.; Burada, E. Association of cytokine gene polymorphisms with osteoarthritis susceptibility. Exp. Med. 2018. [CrossRef] [PubMed]

42. Lyson, K.; McCann, S.M. The Effect of Interleukin-6 on Pituitary Hormone Release in vivo and in vitro. Neuroendocrinology 1991, 54, 262-266. [CrossRef] [PubMed]

43. Spangelo, B.L.; Gorospe, W.C. Role of the cytokines in the neuroendocrine-immune system axis. Front. Neuroendocrinol. 1995, 16, 1-22. [CrossRef]

44. Arzt, E.; Pereda, M.P.; Castro, C.P.; Pagotto, U.; Renner, U.; Stalla, G.K. Pathophysiological Role of the Cytokine Network in the Anterior Pituitary Gland. Front. Neuroendocrinol. 1999, 20, 71-95. [CrossRef]

45. Herman, A.P.; Tomaszewska-Zaremba, D. Effect of endotoxin on the expression of GnRH and GnRHR genes in the hypothalamus and anterior pituitary gland of anestrous ewes. Anim. Reprod. Sci. 2010, 120, 105-111. [CrossRef] [PubMed]

46. Herman, A.P.; Krawczyńska, A.; Bochenek, J.; Haziak, K.; Romanowicz, K.; Misztal, T.; Antushevich, H.; Herman, A.; Tomaszewska-Zaremba, D. The effect of rivastigmine on the LPS-induced suppression of GnRH/LH secretion during the follicular phase of the estrous cycle in ewes. Anim. Reprod. Sci. 2013, 138, 203-212. [CrossRef] [PubMed]

47. Herman, A.P.; Krawczyńska, A.; Bochenek, J.; Antushevich, H.; Herman, A.; Tomaszewska-Zaremba, D. Involvement of prolactin in the meloxicam-dependent inflammatory response of the gonadotropic axis to prolonged lipopolysaccharide treatment in anoestrous ewes. Reprod. Fertil. Dev. 2016, 28, 914. [CrossRef] 
48. Turzillo, A.M.; Nolan, T.E.; Nett, T.M. Regulation of Gonadotropin-Releasing Hormone (GnRH) Receptor Gene Expression in Sheep. Endocrinology 1998, 139, 4890-4894. [CrossRef]

49. Wojtulewicz, K.; Tomaszewska-Zaremba, D.; Herman, A. Endotoxin-Induced Inflammation Suppresses the Effect of Melatonin on the Release of LH from the Ovine Pars Tuberalis Explants-Ex Vivo Study. Molecules 2017, 22, 1933. [CrossRef]

50. Wojtulewicz, K.; Tomaszewska-Zaremba, D.; Krawczyńska, A.; Tomczyk, M.; Przemysław Herman, A. The effect of inflammation on the synthesis of luteinizing hormone and gonadotropin-releasing hormone receptor expression in the pars tuberalis of ewe during different photoperiodic conditions. Can. J. Anim. Sci. 2018, 98, 675-687. [CrossRef]

51. Battaglia, D.F.; Krasa, H.B.; Padmanabhan, V.; Viguié, C.; Karsch, F.J. Endocrine Alterations That Underlie Endotoxin-Induced Disruption of the Follicular Phase in Ewes1. Biol. Reprod. 2000, 62, 45-53. [CrossRef] [PubMed]

52. Russel, A. Body condition scoring of sheep. Practice 1984, 6, 91-93. [CrossRef] [PubMed]

53. Strzetelski, J. Standards for Ruminant Feeding; Instytut Zootechniki PIB: Kraków, Pland, 2009; ISBN 978-83-7607-072-8.

(C) 2020 by the authors. Licensee MDPI, Basel, Switzerland. This article is an open access article distributed under the terms and conditions of the Creative Commons Attribution (CC BY) license (http://creativecommons.org/licenses/by/4.0/). 